Między wykluczeniem a dobrobytem. Refleksja nad społeczna myślą encykliki „Centesimus annus” Jana Pawła II, red. B. Bąk,

R. Kantor, M. Kluz, J. Młyński, Kraków 2017, s. 13-33.

DOI: http://dx.doi.org/10.15633/9788374386289.02

\title{
Przepowiadanie liturgiczne miejscem wychowania społeczeństwa do konsumpcji i kultury bycia
}

Sobór Watykański II, analizując sytuację człowieka epoki nowożytnej, stwierdził, że „w kształtowaniu umysłów coraz większe znaczenie uzyskują nauki matematyczne i przyrodnicze, (...) w sferze praktycznej zaś - wywodzące się z tych nauk gałęzie techniki. To naukowe nastawienie inaczej niż dawniej kształtuje podejście do kultury i sposoby myślenia" (KDK 5). Ten stan niewątpliwie głęboko wpływa na kondycję wiary i życia chrześcijańskiego - przeciwstawienie wiary i nauki, poznania czysto rozumowego i opartego na wierze sprawia, że człowiek łatwiej skłania się w stronę nauki oraz tego, co materialne, oddalając się od religijnej postawy wiary ${ }^{1}$. Stąd nierzadko pojawia się także rozdźwięk między życiem codziennym (obecnością w życiu społecznym, politycznym, pracą) a wiarą, spychaną do roli wewnętrznej, indywidualnej postawy, ograniczonej do przestrzeni

1 Por. A. Lewek, Funkcja kerygmatyczna Kościoła w świetle Vaticanum II. Istota i zadania, z. 2, Warszawa 1984, s. 7. 
Kościoła i życia prywatnego. Tymczasem Magisterium Kościoła, opierając się na objawieniu Bożym, nieustannie rozpoznaje w człowieku prawdę, że jako istota cielesno-duchowa zwrócony jest on ku Bogu, nie tracąc jednak jednocześnie zainteresowania otaczającym światem, którego stał się dzierżawcą. Wynika stąd, że Kościół nie może opuścić człowieka, lecz rozpoznawszy w nim „swoją pierwszą drogę, po której winien kroczyć" ${ }^{2}$, ma obowiązek nie tylko głosić mu i objaśniać prawdy objawione, lecz także wskazywać zasady życia moralnego i społecznego.

Tak właśnie Jan Paweł II argumentuje zainteresowanie Kościoła kwestiami społecznymi - formując swoje dzieci, ma przygotowywać je do odpowiedzialnego życia chrześcijańskiego.

Nauka społeczna interesuje się dziś szczególnie człowiekiem - pisze papież - w jego powiązaniu ze złożoną siecią relacji, charakterystyczną dla współczesnych społeczeństw. Nauki humanistyczne i filozofia pomagają wyjaśnić, na czym polega centralna rola człowieka w społeczeństwie, i uzdalniają go do lepszego rozumienia samego siebie jako istoty społecznej. Tylko wiara jednak objawia mu w pełni jego prawdziwą tożsamość i właśnie z niej wyrasta nauka społeczna Kościoła, która wykorzystując dorobek nauk przyrodniczych i filozofii, pragnie towarzyszyć człowiekowi na drodze zbawienia ${ }^{3}$.

Zgodnie $\mathrm{z}$ tą zasadą $\mathrm{w}$ swojej encyklice papież nawiązuje dialog ze współczesnością, wskazując kierunki realizacji życiowych zadań wszystkim chrześcijanom i ludziom dobrej woli. Ojciec Święty zdaje sobie bowiem sprawę z tego, że Kościół nie może wykonywać swej misji w izolacji od dokonujących się w świecie przemian.

2 Por. Jan Paweł II, Encyklika Redemptor hominis, 14.

3 Jan Paweł II, Encyklika Centesimus annus [dalej: CA], 54. 
Konieczne jest zastanowienie się nad zagadnieniem różnorodnych społeczno-kulturowych uwarunkowań, w jakich Kościół aktualnie pełni i w przyszłości będzie pełnił swoją misję. Jan Paweł II wskazuje wiele z nich w encyklice „Centesimus annus” i podejmuje refleksję nad zjawiskiem konsumizmu oraz kultury bycia oraz konieczności właściwego uformowania chrześcijan względem nich.

Pojęciem „konsumizmu” określa papież taki styl życia, w którym wyżej postawione jest dążenie do tego, by mieć, niż do tego, by być. Jednocześnie wskazuje, że taka postawa wynika wprost z chęci doznawania jak największej przyjemności, złudnej i powierzchownej satysfakcji ${ }^{4}$. Konsumizm jawi się zatem jako zjawisko złożone, dotykające wielu płaszczyzn życia ludzkiego, relacji społecznych, pełnionych przez człowieka zadań, jego pracy, korzystania przez niego z dóbr. Można powiedzieć, że jest szczególnym przejawem współczesnej kultury, pewną koncepcją życia, preferującą dynamikę posiadania zamiast świadomości bycia. Podporządkowuje ona wewnętrzne i duchowe wymiary życia człowieka temu, co materialne i instynktowne. Staje się zatem jedną z możliwych płaszczyzn wyobcowania człowieka, która skutkuje utratą głębszego, autentycznego sensu istnienia ${ }^{5}$. Prowadzi to do sytuacji, w której „człowiek, nie uznając wartości i wielkości osoby w samym sobie i bliźnim, pozbawia się możliwości przeżycia w pełni swego człowieczeństwa i nawiązania relacji solidarności we wspólnocie z innymi ludźmi, do której został stworzony przez Boga" (CA 41). Jako postawa życiowa konsumizm jest przejawem hedonistycznej i utylitarystycznej wizji realizacji człowieka przez siebie samego, która ogarnia swym zasięgiem nie tylko indywidualnego człowieka, lecz także całe struktury i systemy społeczne ${ }^{6}$. Wyraża on zatem fałszywą koncepcję czło-

\footnotetext{
4 Zob. CA 36.

5 J. Gocko SDB, Moralno-społeczne aspekty konsumizmu w świetle społecznego nauczania Kościoła, „Saeculum Christianum“ 6 (1999) nr 2, s. 176.

6 Por. CA 19.
} 
wieka, uwidaczniającą się $\mathrm{w}$ równie fałszywym pojęciu wolności i prawdziwego dobra jednostki. Zaburza stosunek do Boga, ludzi, świata i dóbr służących zaspokajaniu różnorodnych potrzeb. Rzeczą konieczną jest więc wychowanie człowieka ku właściwej wizji życia, tak by postawę „więcej mieć” rozwinąć w „więcej być”. Sam rozwój jest bowiem właściwym człowiekowi sposobem bycia i staje się rzeczywisty, gdy postępuje w zgodzie z najgłębiej rozumianą naturą ludzką. Gdy dotyczy nie tylko dóbr materialnych, dających się użyć, lecz umożliwia także realizację innych potrzeb człowieka: praw osobistych, społecznych, politycznych, tożsamości kulturowej $^{7}$. Jan Paweł II zwraca uwagę na istotne znaczenie kształtowania takiej świadomości, stwierdzając, że

w samym systemie gospodarczym nie ma kryteriów pozwalających na poprawne odróżnienie nowych i doskonalszych form zaspokajania ludzkich potrzeb od potrzeb sztucznie stwarzanych, przeszkadzających kształtowaniu się dojrzałej osobowości. Dlatego pilnie potrzebna jest tu wielka praca na polu wychowania i kultury, obejmująca przygotowanie konsumentów do odpowiedzialnego korzystania z prawa wyboru, kształtowanie głębokiego poczucia odpowiedzialności u producentów i przede wszystkim u specjalistów w dziedzinie społecznego przekazu; konieczna jest także interwencja władz publicznych (CA 36).

Mając w pamięci te słowa, należy zwrócić zatem baczną uwagę na to, iż współczesna konsumpcja jest coraz bardziej powiązana ze światem niematerialnym - lub inaczej ujmując, z wymiarem osobistym (w tym duchowym) i społecznym jednostki ludzkiej.

7 Por. J. W. Gałkowski, Być czy mieć? O właściwy wymiar ludzkiego rozwoju, „Ethos" 3 (1990) nr 3/4, s. 331-332. 
Określając nowe potrzeby i nowe sposoby ich zaspokajania, koniecznie należy się kierować integralną wizją człowieka, która ogarnia wszystkie wymiary jego istnienia i która wymiary materialne i instynktowne podporządkowuje wewnętrznym i duchowym (CA 36).

W tym punkcie ujawnia się prorockie działanie Kościoła, którego zadaniem jest odpowiednie ukierunkowanie chrześcijańskiego postępowania w oparciu o kryterium, jakim jest Ewangelia, zawarta w niej prawda o człowieku, jego doczesnym powołaniu i transcendentnym przeznaczeniu. Nauczanie Kościoła nie może się więc ograniczać tylko do nakreślenia, czym jest zjawisko konsumizmu, czy też wskazania jego niebezpieczeństw i skutków w różnorodnych wymiarach ludzkiego życia - musi towarzyszyć temu wskazanie konkretnych dróg przezwyciężania konsumpcyjnego stylu życia, co w konsekwencji przyczyni się do budowania cywilizacji miłości.

Profetyczna, a zarazem wychowawcza funkcja Kościoła realizuje się na wielu płaszczyznach jego funkcjonowania. Szczególnym areopagiem tego dzieła jest przepowiadanie liturgiczne, w którym w świetle słowa Bożego wierzący mogą dostrzec kierunki i wzorce dla własnego postępowania. Taki kierunek obrała odnowa przepowiadania, zainspirowana nauką Soboru Watykańskiego II, prowadząca do sformułowania homiletycznej zasady, według której głoszenie słowa Bożego ma być interpretacją doświadczeń ludzkich ${ }^{8}$. Kościół jednocześnie objaśnia, że w czytaniach podczas homilii Bóg przemawia do swego ludu, objawia mu tajemnicę odkupienia i zbawienia i podaje pokarm duchowy, a sam Chrystus przez swoje słowo obecny jest

8 Sobór Watykański II, Konstytucja o Liturgii Świętej Sacrosanctum concilium [dalej: KL], 52: „Zaleca się bardzo, by homilia, w której w ciągu roku liturgicznego przedstawia się ma podstawie tekstu świętego tajemnice wiary i zasady chrześcijańskiego życia, była częścią sprawowanej liturgii". 
pośród wiernych ${ }^{9}$. Jak cała liturgia, tak i homilia bowiem, będąca jej integralną częścią, ma na celu uświęcenie człowieka i w konsekwencji doprowadzenie go do zbawienia. Nie jest ona tylko zwykłą informacją o życiu Jezusa Chrystusa, lecz przez nią sam Chrystus jest obecny, naucza, proponuje, zachęca, wzywa, upomina ${ }^{10}$. Zadaniem kaznodziei jest zatem doprowadzenie słuchacza do spotkania z żywym, działającym i nauczającym Zbawicielem. Zasadniczo dokonuje się to $\mathrm{w}$ trzech przestrzeniach interpretacyjnych: sprawowanego misterium, okresu roku liturgicznego oraz konkretnego zgromadzenia wiernych:

Homilia, będąca częścią liturgii (...) stanowi pokarm konieczny dla podtrzymania chrześcijańskiego życia. Winna być wyjaśnieniem jakiegoś aspektu czytań Pisma Świętego albo innego tekstu spośród stałych lub zmiennych części Mszy danego dnia, z uwzględnieniem zarówno obchodzonego misterium, jak i szczególnych potrzeb słuchaczy (OWMR 65).

Przepowiadanie liturgiczne winno zatem uwzględniać sytuację egzystencjalną zgromadzenia, gdyż rzuca ona nowe i konkretne światło na proklamowane słowo i nadaje mu znaczenie. Aktualna sytuacja życiowa ma się stać parabolą sytuacji przeszłej, która opowiada o wspomnianym wydarzeniu zbawczym. W słowie Bożym należy odnajdywać klucz do zrozumienia życia uczestników liturgii. Ono pozwala zrozumieć i rozwiązać problemy ludzkiej codzienności. Głoszenie Ewangelii w Kościele ma bowiem i ten cel, by przemieniać serca i sumienia wiernych, formować je i wychowywać, tak, by „mocą Ewangelii dosięgać i burzyć kryteria ocen, hierarchię dóbr, postawy i nawyki myślowe, bodźce postępowania i modele życiowe rodzaju ludzkiego, które stoją w sprzeczności ze słowem Bożym i planem

9 Por. KL 7.

10 W. Głowa, Liturgia miejscem i źródłem przepowiadania, Przemyśl 1999, s. 113. 
zbawczym"11. Kościół pragnie więc objąć swoją misją człowieka we wszystkich wymiarach i uwarunkowaniach życia społecznego. Nowe konteksty hermeneutyczne słowa Bożego w liturgii tworzone są przez wydarzenia z życia Kościoła, z życia kultury (przemiany kulturowe, nauki antropologiczne, media), z życia społecznego (wspomnienie wydarzeń ukazujących zbieżność z tekstami biblijnymi, co pozwala spojrzeć na nie w nowy sposób - znaki czasu), z życia indywidualnego i rodzinnego (różnorodne doświadczenia ludzkie, realizacja powołania życiowego) ${ }^{12}$. Wszystko to staje się polem obecności nauczania społecznego Kościoła w przestrzeni przepowiadania słowa Bożego w liturgii. To szczególnie istotne, ponieważ o ile tematyka społeczna pojawia się w programie nauczania katechezy szkolnej, o tyle na przekazanie konkretnych treści dorosłemu chrześcijaninowi trzeba poszukać dogodnego miejsca. Okazuje się, że przepowiadanie homilijne stwarza ku temu swoistą okazję. Sam Chrystus bowiem nie uchyla się od kwestii społecznych, a w przypowieściach dotyka choćby relacji pracownik-pracodawca ${ }^{13}$ czy też wprost odnosi się do kwestii płacenia podatków ${ }^{14}$. Należy tu oczywiście jasno zastrzec, że ambona nie jest miejscem systematycznego wykładu nauki społecznej Kościoła. Nie oznacza to jednak, że w kazaniach i homiliach można pomijać zagadnienia odnoszące się do życia społecznego. Milczenie w tej kwestii mogłoby sprawiać wrażenie, że społeczne nauczanie skierowane jest tylko do niektórych, że stanowi pewnego rodzaju dodatek do prywatnej wiary i praktyk religijnych chrześcijan głębiej zaangażowanych społecznie czy politycznie. Tymczasem ma ono stanowić „nieodzowny element nauczania powszechnego,

11 Paweł VI, Adhortacja apostolska Evangelii nuntiandi o ewangelizacji w świecie współczesnym, 19.

12 S. Dyk, Co głosić, aby wierzyli? Studium homiletyczne lekcjonarza mszalnego, Lublin 2013, s. 63.

13 Por. Mt 20, 1-15.

14 Por. Mt 22, 15-22. 
skierowanego do wszystkich chrześcijan w Kościele - a także, o ile to możliwe: poza Kościołem ${ }^{15}$ ".

W tym miejscu może zrodzić się pytanie, które z treści społecznych winny być obecne w przepowiadaniu. Wskazuje na to przede wszystkim oczywiście samo słowo Boże proklamowane w konkretnych okolicznościach. Biblia nie stanowi przecież zbioru abstrakcyjnych idei czy teoretycznych zasad funkcjonowania, lecz jest zapisem doświadczeń ludzkich w Bożej historii zbawienia. Dotykają one zarówno cielesnego, jak i duchowego wymiaru człowieczeństwa oraz poszczególnych sytuacji ludzkiego życia. Doświadczenia te obecne są również w życiu współczesnego człowieka, z tą różnicą, że zmienność świata wymaga spojrzenia na nie i nazwania ich na nowo ${ }^{16}$. Takie przeżycia indywidualne i zjawiska społeczne, oświetlone mądrością słowa Bożego, stają się nie tylko zrozumiałe dla człowieka, lecz są także miejscem jego osobistego spotkania z Bogiem. Nauka społeczna Kościoła zbudowana jest przecież na Ewangelii, wskazującej ludziom drogę zbawienia, urzeczywistniającą się w pełni w wymiarze eschatologicznym. Wymiar ten nie pomniejsza jednak znaczenia doczesności. Przeciwnie, przyczynia się do jej wyeksponowania, gdyż człowiek żyje „tu i teraz” i właśnie to „teraz” jest od niego zależne. Stąd też w Bożym porządku zbawienia, które Kościół uważa za swoją właściwą misję, mieści się wszystko to, co stanowi o prawdziwym postępie i rozwoju człowieka.

Człowiek ze swej natury jest istotą społeczną. Od chwili przyjścia na świat związany jest ze swoim środowiskiem rodzinnym, następnie wchodzi w relacje z kolejnymi społecznościami i wspólnotami (rówieśniczą, klasową, szkolną itd.), aż po wspólnotę narodu i społeczność państwową. Wspólnoty te silnie oddziałują na człowieka,

15 Jan Paweł II, Nauczanie społeczne Kościoła integralnq częściq jego misji, RzymKraków 1996, s. 65.

16 G. Siwek CsSR, Blaski i cienie współczesnego przepowiadania. Przewodnik dla kaznodziejów i homilistów, Kraków 2007, s. 56 (Redemptoris Missio, 25). 
kształtują go w sposób tak rozległy, że wpływ ten obejmuje rozumienie świata, myślenie, postępowanie, uznawane wartości, styl życia, konfrontując także z prawdą i wymaganiami Ewangelii. Prowadzi to do stworzenia całego porządku społecznego, który może umożliwiać człowiekowi jego integralny rozwój i realizację życiowego powołania, bądź je utrudniać, wikłając go nawet w struktury zła ${ }^{17}$. Dlatego Kościół zobowiązany jest stać na straży dobra człowieka, demaskować zło i jego struktury oraz wskazywać takie rozwiązania, które pozostają w zgodzie z objawioną prawdą Bożą. W tym kontekście przepowiadający powinien być kimś, kto przerzuca pomosty pomiędzy głoszonym słowem Boga a teraźniejszością, w której to słowo nabiera znaczenia. Współczesne przemiany społeczno-kulturowe spełniają funkcję filtrów sprzyjających kaznodziejskiemu przekazowi bądź go blokujących. Myśl tę podejmuje wprost Jan Paweł II, wskazując, że nauczanie i upowszechnianie myśli społecznej Kościoła nie tylko wchodzi w zakres misji ewangelizacyjnej, lecz także jest jej wyrazem $^{18}$. Zadaniem Kościoła jest bowiem wskazywanie słusznej drogi i podejmowanie wyzwań współczesności w obliczu różnorakich ideologii tracących wiarygodność. Konkurencja na „rynku” światopoglądowym" sprawia, że Kościół staje się tylko jednym z segmentów budujących społeczeństwa pluralistyczne. Podobnie jak instytucje społeczne, grupy i jednostki ludzkie, Kościół konkuruje i współzawodniczy $\mathrm{z}$ innymi podmiotami $\mathrm{w}$ urzeczywistnianiu własnych

17 Por. J. Kupny, Nauka społeczna w przepowiadaniu, w: Integralne kształcenie kaznodziei, red. W. Broński, Lublin 2006, s. 244.

18 CA 5: „Tak bowiem jest, że nauczanie i upowszechnianie nauki społecznej wchodzi w zakres misji ewangelizacyjnej Kościoła i stanowi istotną część orędzia chrześcijańskiego, ponieważ ukazuje jego bezpośrednie konsekwencje dla życia społeczeństwa i czyni codzienną pracę i walkę o sprawiedliwość elementem świadectwa o Chrystusie Zbawicielu. Doktryna ta jest także źródłem jedności i pokoju, pomagającym rozwiązywać konflikty, które nieuchronnie powstają w dziedzinie gospodarczo-społecznej. Dzięki niej staje się możliwe przeżywanie nowych sytuacji bez poniżania transcendentnej godności osoby ludzkiej w sobie samym i w przeciwnikach oraz wybór właściwych rozwiązań". 
celów $^{19}$. Zważywszy na to, że człowiek, przynależąc do wielu grup społecznych, styka się z różnorodnymi, nieraz sprzecznymi systemami wartości, należy stwierdzić, że sprzyja to relatywizacji jego poglądów, powiększeniu przestrzeni indywidualnej wolności i wyborów, które nie zawsze są zgodne prawdą Ewangelii i przedstawionym w niej przeznaczeniem człowieka.

Bogactwo tematów poruszonych w encyklice Centesimus annus jest źródłem wielorakich inspiracji, które mogłyby być wykorzystane w głoszeniu słowa i znaleźć swoje odzwierciedlenie w trzecim kręgu interpretacyjnym przepowiadania, jakim jest sytuacja egzystencjalna słuchaczy. Co prawda sporo miejsca zajmuje w encyklice analiza upadku ideologii marksizmu i realnego socjalizmu, co w czasie powstania dokumentu niewątpliwie miało doniosły wpływ na życie jednostek i całych społeczności, ale autor wskazuje również na inne kwestie, a także niebezpieczeństwa zagrażające wolności osoby, sumieniu człowieka, prawu naturalnemu i objawieniu. Encyklika ta nie jest tylko analizą i krytyczną oceną „dzikiego”, kapitalizmu, lecz także przede wszystkim przypomnieniem, że bez dobrego i prawdziwego spojrzenia na osobę ludzką niemożliwe jest skuteczne i poprawne rozwiązanie problemów życia społecznego, politycznego i gospodarczego $^{20}$. To całościowe spojrzenie na człowieka dokonuje się wszakże nie inaczej, jak przez pryzmat słowa Bożego. Dlatego dobór tematyki nauczania społecznego Kościoła w przepowiadaniu liturgicznym winien w pierwszym rzędzie uwzględniać czytania mszalne danego dnia i równocześnie szczególne potrzeby i okoliczności życia słuchaczy. Tam, gdzie zauważa się brak poszanowania godności i praw człowieka, nie można uchylać się od podjęcia tej problematyki. Jawna niesprawiedliwość, krzywda, nadużycia władzy, działania systemu

19 Por. R. Kamiński, Duszpasterstwo w społeczeństwie pluralistycznym, Lublin 1997, S. 28-30.

20 J. Majka, Komentarz do encykliki Jana Pawła II "Centesimus annus", w: Jan Paweł II, Encyklika Centesimus annus, Wrocław 1991, s. 126-127. 
totalitarnego, terror wymagają wniesienia jasnego światła nauczania społecznego Kościoła o miłości, sprawiedliwości i pokoju jako głównych wartościach przesłania ewangelicznego ${ }^{21}$. Szczególną formą przepowiadania społecznego mogą być homilie i kazania okolicznościowe, wygłaszane z okazji uroczystości religijno-patriotycznych. Stanowią one jedną z najdogodniejszych okazji, by przekazać słuchaczom treść społecznego nauczania Kościoła. Przykładem tego typu włączania nauki o kwestiach społecznych do konkretnej sytuacji życiowej słuchaczy jest nauczanie samego Jana Pawła II podczas jego licznych pielgrzymek: w konkretnych społecznościach poruszał on palące problemy życia obywatelskiego, politycznego, wolności i godności człowieka. Również pielgrzymki do Polski, mające charakter ściśle religijny, ukazały, w jaki sposób można podejmować trudne problemy życia społecznego, politycznego i gospodarczego, pozostając na gruncie przepowiadania słowa Bożego ${ }^{22}$. W tym świetle można także spojrzeć na opisaną w encyklice postawę konsumpcyjnego stylu życia oraz zauważone przez papieża zagrożenia i wskazać możliwości ich pokonania.

Jan Paweł II, charakteryzując postawę konsumpcyjną i zjawisko konsumizmu, zauważa, że

odwoływanie się bezpośrednio do instynktów człowieka i ignorowanie na różne sposoby jego wolnej i świadomej natury osobowej może prowadzić do wytworzenia się nawyków konsumpcyjnych i stylów życia obiektywnie niegodziwych lub szkodliwych dla fizycznego i duchowego zdrowia (CA 36).

21 Zob. J. Kupny, Nauka społeczna w przepowiadaniu, dz. cyt., s. 249.

22 Przykładowo: o godności i prawach człowieka - Homilia podczas Mszy św. na placu Zwycięstwa (Warszawa 1979); o ludziach sumienia - Homilia w czasie Mszy św. odprawionej na wzgórzu "Kaplicówka" (Skoczów 1995), w: Jan Paweł II, Pielgrzymki do Ojczyzny. Przemówienia i homilie, red. J. Poniewierski, Kraków 2005. 
Nie ulega zatem wątpliwości, że potrzeba wskazywać człowiekowi odpowiednią drogę uchronienia się od zagrożeń wynikających $\mathrm{z}$ takiego działania i przypominać mu o niej. Wychowanie do konsumpcji i kultury bycia oznaczać ma zatem uwrażliwienie wierzących na wskazane niebezpieczeństwa, co znajduje odzwierciedlenie w liturgicznym przepowiadaniu słowa. Ta bowiem profetyczna i wychowawcza funkcja Kościoła w przezwyciężaniu konsumpcyjnego stylu życia jest o tyle istotna, że w samym systemie gospodarczym zauważa się brak kryteriów pozwalających na poprawne odróżnienie nowych i doskonalszych form zaspokajania ludzkich potrzeb od potrzeb kreowanych w sposób sztuczny. Okazuje się, że ustalenie zakresu i rodzaju potrzeb wymaga uprzedniego sformułowania konkretnej koncepcji rozwoju osobowego. Nieodzowne staje się tu zatem odwołanie do integralnej wizji osoby ludzkiej, w której nie da się pominąć elementu transcendentnego w człowieku oraz jego ostatecznego przeznaczenia ${ }^{23}$.

Przezwyciężaniu konsumpcyjnego stylu życia służyć będzie budowanie świata bardziej ludzkiego, w którym podstawowym prawem stanie się poszanowanie niezbywalnej godności osoby, troska o dobro człowieka i jego odpowiedzialność za otaczający świat. Papież stwierdza:

Pragnienie, by żyć lepiej, nie jest niczym złym, ale błędem jest styl życia, który wyżej stawia dążenie do tego, by mieć, aniżeli być, i chce więcej mieć nie po to, aby bardziej być, lecz by doznać w życiu jak najwięcej przyjemności. Dlatego trzeba tworzyć takie style życia, w których szukanie prawdy, piękna i dobra oraz wspólnota ludzi dążących do wspólnego rozwoju byłyby elementami decydującymi o wyborze jakości konsumpcji, oszczędności i inwestycji. W tym kontekście nie mogę ograniczyć się tylko do

23 J. Gocko, Moralno-społeczne aspekty konsumizmu..., dz. cyt., s. 190. 
przypomnienia obowiązku miłosierdzia, czyli obowiązku wspomagania z tego, co „zbywa”, a czasem nawet z tego, co „potrzebne”, by dać ubogiemu to, co dla niego jest niezbędne (CA 36).

Idea cywilizacji miłości według papieża jest rzeczywistością dynamiczną, w której dostrzec można priorytety, takie jak: pierwszeństwo osoby przed rzeczą, prymat ducha nad materią, przewaga „być” nad „mieć”, pierwszeństwo miłosierdzia nad sprawiedliwością, ubóstwa przed bogactwem, etyki przed techniką, prawdy przed ideologią, praw jednostki przed prawami państwa ${ }^{24}$. Idea ta jest próbą przywrócenia właściwego porządku rzeczy w oparciu o pełną prawdę o człowieku, wbrew cywilizacji konsumpcji zrodzonej z zagubienia słusznej hierarchii wartości i redukcyjnego spojrzenia na ludzką wolność. W obliczu takich zjawisk, dokonujących głębokich przemian w spojrzeniu człowieka na samego siebie, na świat, cywilizację, kulturę i religię, należy, z uwzględnieniem ich skutków, głosić słowo Boże w zmiennych warunkach miejsca i czasu ${ }^{25}$. Tempo dokonujących się przemian stało się tak szybkie, że aktualnie odchodzi w przeszłość dotychczasowy obraz człowieka, świata i kultury.

Papież zauważa, że w systemie społeczno-gospodarczym nie istnieją jasne zasady umożliwiające oddzielenie (a co za tym idzie wybór) potrzeb koniecznych (pożywienie, ubranie, mieszkanie), od potrzeb sztucznie stwarzanych. Wskazuje przy tym na zagrożenia i nadużycia, jakie pociąga za sobą sztuczna konsumpcja. Zarówno bowiem nadmiar, jak i niedobór dóbr mogą stać się źródłem tych samych w swej istocie postaw, określonych przez Ojca Świętego mianem konsumizmu. Wśród trudnych do opanowania zagrożeń, stanowiących szczególne niebezpieczeństwo dla zdrowia, papież wymienia

24 T. Borutka, Nauczanie społeczne papieża Jana Pawła II, Kraków 1994, s. 289.

25 O przemianach współczesności i ich wpływie na kaznodziejstwo pisze m.in. A. Draguła, Słuchanie wędrowca. Kaznodziejstwo w czasach postmoderny, „Więź" 45 (2002) nr 6, s. 56-64. 
używanie narkotyków, prowadzące do destruktywnej interpretacji ludzkich potrzeb, a także "pornografię i inne formy konsumizmu, [które] wykorzystując nieodporność jednostek słabych, mają wypełnić duchową pustkę, jaka powstaje w człowieku" (CA 36). O próbie koniecznego w danym momencie zaspokojenia szeroko pojętych potrzeb ciała, poczynając od najbardziej podstawowych, można przeczytać na kartach Ewangelii. Patrząc z perspektywy przepowiadania, należałoby tu przypomnieć scenę kuszenia Jezusa na pustyni i pierwszą pokusę, jaką szatan podsuwa Zbawicielowi ${ }^{26}$. Proponując zamianę kamieni w chleb, pragnie skierować myśl i działanie Chrystusa na konieczne i pierwszorzędne - w jego mniemaniu - potrzeby ludzkie. Jezus jednak daje mu odpór, wskazując, że właściwą postawą człowieka nie jest absolutyzowanie potrzeb materialnych, lecz wpisanie ich w hierarchię wszelkich potrzeb ludzkich, wśród których szczególne miejsce zająć mają te duchowe i religijne. Podążając za tym wskazaniem Zbawiciela, Kościół ma wskazywać drogę i prowadzić człowieka ku przezwyciężaniu postaw absolutyzujących konsumpcję, ku ukształtowaniu umiejętności dokonywania właściwych wyborów w tej kwestii. Wynika to z jego nieustannej troski o człowieka, a realizuje się nie inaczej, jak w nauczaniu społecznym i wychowaniu moralnym. W realizacji tego celu nie może zabraknąć postawy nawrócenia, czyli podejmowania nieustannie na nowo trudu przezwyciężania własnego egoizmu. Słuszne będzie zatem zwrócenie bacznej uwagi na rozbudzanie potrzeby uczestnictwa w życiu społecznym, rozumianego jako budowanie wspólnoty opartej na zasadach solidarności, wzajemnej pomocy i wsparcia. Jest to jednocześnie droga do pokonania kolejnego z zagrożeń wskazanych w encyklice, a mianowicie postawy alienacji.

Alienacja połączona $\mathrm{z}$ utratą autentycznego sensu istnienia jest zjawiskiem obecnym również w rzeczywistości społeczeństw 
zachodnich. Występuje ona w sferze konsumpcji, gdy człowiek wikła się w sieć fałszywych i powierzchownych satysfakcji, podczas gdy powinien spotkać się z pomocą w autentycznej i konkretnej realizacji swojej osobowości. (...) Należy sprowadzić pojęcie alienacji do wizji chrześcijańskiej, dostrzegając, że alienacja polega na odwróceniu relacji środków i celów: człowiek, nie uznając wartości i wielkości osoby w samym sobie i w bliźnim, pozbawia się możliwości przeżycia w pełni własnego człowieczeństwa i nawiązania tej relacji solidarności i wspólnoty z innymi ludźmi, dla której został stworzony przez Boga (CA 41).

Nieodpowiedzialne korzystanie z dóbr prowadzi do bierności w sferze dzielenia się nimi. Tymczasem używanie i konsumowanie jakichkolwiek dóbr zawsze powinno służyć rozwojowi, samorealizacji człowieka i umiejętności pomnażania ich dla dobra innych. Taka postawa jest zgodna zarówno z zamysłem Bożym, jak i z naturą samego człowieka. Solidarność międzyludzka pokonuje niezdrowy indywidualizm, hedonistyczne wygodnictwo i materializm. Przesłanie słowa Bożego w tym kontekście jest bardzo jasne, a zauważanie potrzeb drugiego człowieka i wzajemne wsparcie jest osnową wielu nauk Chrystusa ${ }^{27}$. Niewątpliwie zatem w przepowiadaniu znajdzie się miejsce na podjęcie tej kwestii nauczania społecznego: w miejsce indywidualistycznej samorealizacji trzeba położyć nacisk na pielęgnowanie - nie zawsze dziś popularnej - gotowości do wyrzeczenia i „noszenia brzemion innych" (Ga 6, 2). Przejawem podejmowania odpowiedzialności za kształt życia własnego i innych jest wychowywanie do postawy służby, kultywowania prowadzących ku niej postaw i wartości, ze szczególnym uwzględnieniem idei wolontariatu, którą Kościół „rozwija i wszystkich zachęca do udziału w popieraniu inicjatyw w tym zakresie" (CA 49). Jan Paweł II zauważa, że każdy 
człowiek winien sam dać odpowiedź temu Bożemu wezwaniu, gdyż uświadomienie sobie własnej godności, a przez to także godności bliźniego, jest szczytem człowieczeństwa ${ }^{28}$. Takie postępowanie przynosi również prawdziwą wolność, gdyż umożliwia ofiarowanie daru z siebie samego, co według słów papieża możliwe jest dzięki podstawowej „zdolności transcendencji” osoby ludzkiej. Bóg bowiem, stwarzając człowieka, zaszczepił w nim zdolność do ponoszenia ofiary na rzecz bliźnich, by ostatecznie ofiarować swoje życie samemu Bogu - dawcy tegoż życia. Przykład Chrystusa składającego najwyższą ofiarę dla zbawienia rodzaju ludzkiego jest nieprzemijającym wzorem i motywacją do pokonywania siebie i dążenia do osiągnięcia transcendentnego przeznaczenia:

człowiek, który troszczy się wyłącznie albo głównie o to, by mieć i używać, niezdolny już do opanowywania własnych instynktów i namiętności oraz do podporządkowania ich sobie przez posłuszeństwo prawdzie, nie może być wolny: posłuszeństwo prawdzie o Bogu i człowieku jest pierwszym warunkiem wolności, pozwala człowiekowi uporządkować własne potrzeby, własne pragnienia i sposoby ich zaspokajania według właściwej hierarchii, tak by posiadanie rzeczy pomagało mu wzrastać (CA 41).

Przy spełnianiu tego zadania człowiek słusznie winien jednak oczekiwać pomocy ze strony rodziny, szkoły, a przede wszystkim Kościoła.

Zdolność do ofiary i służby bliźniemu płynąca z postawy miłości i wzajemnego szacunku to umiejętność, którą człowiek w pierwszym rzędzie nabywa dzięki dobremu przykładowi najbliższych. Papież zauważa, że środowisko rodzinne jest miejscem, w którym człowiek uczy się kochać i być kochanym. „Chodzi tu o rodzinę opartą na 
małżeństwie, gdzie wzajemny dar z samego siebie, mężczyzny i kobiety, stwarza takie środowisko życia, w którym dziecko może się urodzić i rozwijać swe możliwości, nabywać świadomość własnej godności i przygotować się do podjęcia swego jedynego i niepowtarzalnego przeznaczenia" (CA 39). Wzajemne wspieranie się małżonków, zrodzenie i wychowanie potomstwa, troskliwość międzypokoleniowa ma wyzwalać od chęci „posiadania siebie” i pokusy przenoszenia konsumistycznych mechanizmów zachowań na obszar wychowania, rodziny i stosunku do osób starszych ${ }^{29}$. Takie działanie ma wynikać wprost ze zrozumienia i przyjęcia podstawowej koncepcji osoby ludzkiej i jej niepowtarzalnej wartości, według której człowiek jest istotą chcianą przez Boga, przez Niego umiłowaną, stworzoną na Jego obraz i podobieństwo ${ }^{30}$ oraz zdolną do budowania relacji miłości, której najlepszym obrazem jest właśnie rodzina. W przepowiadaniu nie sposób więc pominąć nauczania o tej podstawowej komórce życia społecznego. Z pomocą przychodzi tu sam układ roku liturgicznego, w którym podsuwane są konkretne tematy. Dla przykładu: okres Narodzenia Pańskiego skłania do podjęcia problematyki prawa do życia, jego ochrony w każdym czasie i godności osoby ludzkiej. Przypadające w tym okresie święto Świętej Rodziny to okazja do przedstawienia nauki o małżeństwie i rodzinie, o wychowawczych obowiązkach

29 Konsumizm wpływa negatywnie na postrzeganie współczesnej rodziny. W społeczeństwie konsumizmu żona, mąż lub dzieci mogą stać się przedmiotami wyboru „posiadać lub nie posiadać", jak rzeczy. Drugi człowiek bywa traktowany jak dobro konsumpcyjne czy towar, co jest konsekwencją przekonania, że każdy ma prawo dążyć do jak największej przyjemności. W związku mężczyzny z kobietą, najczęściej podejmowanego na próbę, nie ma miejsca na ponoszenie ofiar na rzecz ukochanej osoby ani nawet na poczucie odpowiedzialności za partnera. Taki konsument raczej rezygnuje ze stałych związków, odkłada rodzenie i wychowanie dzieci, by jak najdłużej móc dokonywać kolejnych wyborów. Zatem konsumizm stwarza zagrożenie dla istnienia rodziny jako instytucji społecznej. Zob. J. Mariański, Kościół a współczesne problemy społeczno-moralne. Kwestie wybrane, Lublin 1992, s. 127.

30 Por. CA 11. 
rodziców, a także o wzajemnej odpowiedzialności członków rodziny ${ }^{31}$. Kaznodzieja, pochylając się nad tymi tematami, otwiera przed słuchaczami skarbiec Kościelnego nauczania promującego rolę rodziny w budowaniu cywilizacji miłości.

Z problemem konsumizmu na łamach encykliki papież łączy także ściśle kwestię ekologiczną. Ojciec Święty interpretuje nieodpowiedzialną dewastację środowiska naturalnego jako przejaw błędnej postawy konsumpcyjnej, wyrażającej się w chęci samowolnego i nieograniczonego zaspokajania własnych potrzeb:

Człowiek, który odkrywa swą zdolność przekształcania i w pewnym sensie stwarzania świata własną pracą, zapomina, że zawsze dzieje się to w oparciu o pierwszy dar, otrzymany od Boga na początku w postaci rzeczy przezeń stworzonych. Człowiek mniema, że samowolnie może rozporządzać ziemią, podporządkowując ją bezwzględnie własnej woli, tak jakby nie miała ona własnego kształtu i wcześniejszego, wyznaczonego jej przez Boga przeznaczenia, które człowiek, owszem, może rozwijać, lecz któremu nie może się sprzeniewierzać. Zamiast pełnić rolę współpracownika Boga w dziele stworzenia, człowiek zajmuje Jego miejsce i w końcu prowokuje bunt natury, raczej przez niego tyranizowanej, niż rządzonej (CA 37).

Pozycja człowieka wobec rzeczy stworzonych, a szczególnie wobec natury nie może więc mieć charakteru władzy absolutnej. Kościół ma obowiązek nieustannie przypominać tę prawdę, zapisaną wprost na kartach Biblii. Owszem, obowiązkiem człowieka jest zarządzanie stworzeniem i opiekowanie się nim, lecz zawsze według zamysłu Bożego i praw, jakie wskazuje sam Stwórca. Kaznodziejski przekaz tej prawdy ma chronić człowieka przed sprzeniewierzeniem się 
Bożym wskazaniom i powołaniu, jakie On sam dał człowiekowi, tak by chronić go przed zaciągnięciem moralnej winy, a uprzedzająco pobudzać do rozpalania w sobie cnoty roztropności i umiarkowania.

Głoszenie Ewangelii winno pobudzać człowieka nie tylko do dojrzałej wiary, lecz także do dawania świadectwa chrześcijańskiego, do oddziaływania na środowiska tworzące życie polityczne, społeczno-gospodarcze i kulturalne. Przyjęcie i wypełnienie ewangelicznego orędzia wprowadza w ludzką egzystencję nową nadzieję oraz tworzy warunki życia godnego człowieka. Odpowiedzialność Kościoła zawiera się więc także w promowaniu i podtrzymywaniu właściwego sytemu wartości i kształtowaniu odpowiedniego „stylu bycia”. Jan Paweł II oczekuje, że cel ten można osiągnąć dzięki pracy edukacyjno-wychowawczej i kulturotwórczej. Mówiąc o „stylach życia”, papież zaleca, by stylom szkodliwym przeciwstawiać te, które wiążą się z szukaniem prawdy, piękna i dobra, i zmierzać w ten sposób do przekształcania kultury masowej. To w niej - według intuicji Jana Pawła II - kształtują się i lansują określone „style życia”, najczęściej konsumpcyjne, a zatem w niej dokonać się musi zasadnicza odnowa systemu wartości ${ }^{32}$. Uwzględniając wzajemne powiązania kultury i człowieka, Ojciec Święty zaznacza, że „zrozumienie człowieka jest bardziej wyczerpujące, gdy widzi się go w kontekście kultury, poprzez język, historię i postawy przyjmowane wobec podstawowych faktów egzystencjalnych, takich jak narodziny, miłość, praca, śmierć” (CA 24). Każdy zatem, żyjąc „w kulturze”, ma także obowiązek wzbogacać ją i kształtować. Zadanie to „wymaga włączenia się całego człowieka, który wyraża w niej swój zamysł twórczy, inteligencję, znajomość świata i ludzi. Angażuje w nią także swą umiejętność panowania nad sobą, osobistego poświęcenia, solidarności i pracy dla rozwoju dobra wspólnego.” (CA 51). Rolą Kościoła

32 R. J. Neuhaus, Biznes i ewangelia. Wyzwanie dla chrześcijanina-kapitalisty, przeł. B. Szlachta, Poznań 1993, s. 213nn. 
wskazaną w encyklice jest rozwijanie właściwych postaw; praca ta rozpoczyna się wewnątrz ludzkiego serca, w którym jest źródło „rzeczy złych i dobrych" ${ }^{33}$. Kształtowanie właściwych postaw ma swoje źródło w darze odkupienia, przez który Chrystus nie tylko zbawił, lecz także zjednoczył wszystkich ludzi, czyniąc ich odpowiedzialnymi za siebie nawzajem.

Tak rozumiana „kultura bycia” nie może ograniczać się tylko do najbliższych (rodziny, narodu czy państwa), lecz ma obejmować ma całą ludzkość w taki sposób, że jeden dla drugiego nie pozostaje obcy czy obojętny. Każdy chrześcijanin, na podobieństwo Zbawiciela, ma dążyć do wypracowania w sobie takiej postawy, która będzie prowadzić do doskonałości, na wzór doskonałości i miłości Ojca Niebieskiego. Przepowiadane w Kościele słowo Boże jest niewątpliwie szczególnym drogowskazem w kształtowaniu opisywanej przez papieża odpowiedzialności -sam autor encykliki wskazuje zresztą konkretne teksty biblijne: Rdz 4, 9; Łk 10, 29-37; Mt 25, 31$46^{34}$. We współczesnym świecie pierwszym zadaniem wierzących w Chrystusa ma być bowiem ponowne odkrycie nowości własnej wiary oraz jej mocy, tak by w Jezusie rozpoznać i przyjąć prawdę, którą trzeba żyć - to znaczy żyć tak, jak On żył, miłując ponad wszystko Boga i braci, co wprost staje się zaprzeczeniem postawy zorientowanej na konsumpcję i użycie ${ }^{35}$.

Współczesny człowiek bardzo często boryka się z wieloma problemami, które zasiewają wewnętrzny niepokój w jego sercu. W konsekwencji rodzi się w nim wewnętrzny lęk o kształt codzienności, o przyszłość. Poszukując prawdy, szuka sensu własnego życia i odpowiedzi na nurtujące pytania: o sprawiedliwość, to, jak budować właściwe relacje społeczne. Gdzie ma je znaleźć? Przede wszystkim w orędziu zbawczym zawartym w Piśmie Świętym. Ponieważ jednak

33 Por. Mk 7, 14-23.

34 Zob. CA 51.

35 J. Gocko, Moralno-społeczne aspekty konsumizmu..., dz. cyt., s. 194. 
może natrafić na trudności interpretacyjne, przed kaznodzieją stoi zadanie dokonania aktualizacji prawd ewangelicznych. Chrystus jest Tym, który chce zbawić człowieka w jego codzienności i którego słowo jest rozwiązaniem jego życiowych problemów ${ }^{36}$. Przepowiadanie Dobrej Nowiny ma doprowadzić poszukującego człowieka do wychodzącego mu naprzeciw Boga. Jest to więc proces komunikacji zarówno w swoim wymiarze teologicznym, jak i antropologicznym. Problem w tym, by homilista nie ograniczył się do teoretycznego formułowania wniosków wypływających z doświadczeń bohaterów biblijnych, lecz potrafił przedstawić je w taki sposób, by współczesny słuchacz mógł się w nich odnaleźć, zmierzyć się z własnymi konkretnymi problemami i codziennością. Konsumpcyjny styl życia stawia człowieka przed wyzwaniem wymagającym nieustannego dokonywania różnicujących wyborów w taki sposób, by nie utracić podstawowej prawdy o prymacie osoby nad rzeczą. Człowiek nie może zrezygnować $\mathrm{z}$ siebie, $\mathrm{z}$ właściwego sobie miejsca, nie może stać się niewolnikiem rzeczy i potrzeb, szczególnie sztucznie stwarzanych, lecz pragnąc żyć lepiej, ma dążyć i dojrzewać do ubogacenia swojego „być”, wyniesionego ponad „mieć”. Ukształtowanie takiej postawy to wychowawcze zadanie Kościoła, którego jedną z przestrzeni pozostaje głoszenie Ewangelii.

36 Por. S. Dyk, Ewangelizacyjny charakter przepowiadania słowa Bożego, „Przegląd Homiletyczny" 5-6 (2001-2002), s. 31. 
- 